\title{
The Depiction of Erotism In Spanish and Indonesian Song Lyrics
}

\author{
Adinda Rizki Ramadhani, UniversitasAirlangga
}

\begin{abstract}
Culture and media are two beings that cannot be separated and influence each other, in which different cultures can be reflected through different media productions. One of those is by music or song as the media. Two cultures, Spanish and Indonesian cultures, are highlighted in this study due to the fact that those cultures have relatively different backgrounds of culture. By using two songs produced in those two countries as the objects of the study, this study aims to figure out how Spanish and Indonesian cultures picture erotism and vulgarity in it. The scrutinization of the song lyrics are done by utilizing descriptive qualitative methods, as well as by referring to the theory of erotism. In results, the song produced in Spain is discovered more explicit in stating the words related to erotism. On the other hand, the Indonesian song tends to use more implicit words in expressing erotism and vulgarity.
\end{abstract}

Keywords: culture; erotism; Indonesia; song lyrics; Spain

\section{Introduction}

When talking about media, the one thing to notice is that media cannot be separated from culture, or the culture. Media and culture are affecting one another, in which the culture predisposes the contents that media is going to deliver and the media conveys the contents that undoubtedly influence the life of the society (Dakroury, 2014). For example, in Indonesia, particularly during the campaign of presidential election, many of mass media broadcast the news related to the presidential candidates that later will alter the society's paradigm as well as their behavior in daily situation after getting certain information from the media.

Media, or in more specifically communication media, can be in various forms, namely books, newspapers, magazines, television shows, radio broadcastings, films, advertisements, games, and musics or songs. The things included in media as films, advertisments, and musics, are closely related to popular culture or pop culture. Pop culture itself can be defined as a matter that is directly associated with human's daily life (Delaney, 2015). Similar to culture in general, pop culture also shapes the contents in media and at the same time, are shaped by media. One of the most appealing pop cultures is in the form of music or song.

It has been described that culture and media affect one another. As to be noted, different countries come with different cultures. Captivatingly, the culture differences are somehow reflected in the music production in different countries, especially on the matter of the meanings transmissions. For instance, the song production in African-American country before 1998 tended to concern on how love is depicted as something sweet, intimate, and commitmentrelated (Dukes, Bisel, Borega, Lobato, \& Owens, 2003). In comparison, as they added, the love songs produced in America after 1998 encountered meaning shifts, due to the increase of individuality levels as well as the emergence of women movement in America.

In eastern cultures and customs as Indonesia, namely the collectivism culture, the things appear in the society need to be in accordance with the norms and the customs applied (Triandis, 2001). The things beyond the norms and customs will be considered taboo to be talked publicy in the countries with collectivism culture, as Indonesia. In contrast, in western countries and cultures, for instance, America and Spain, in which the individualism culture plays immense role in the people's life, one tends to act liberally without considering the norms and customs in his/her circumstances (Triandis, 2001). In addition, in individualism culture, one is able to voice their opinion as long as it does not contravene the law (Triandis, 2001). Apparently, the named cultures; collectivism and individualism, influence the music or songs production in the countries with those two different cultures as well. The differences can be seen in the meaning, the lyrics, and the genre of the music. Things including sex, erotism, and 
vulgarity are the things considered taboo to be publicly spoken in collectivism culture, such as in Indonesia, for the reason that those things are said to be violating the existed norms and customs. On the one hand, the things that aforementioned, to be precise, sex, erotism, and vulgarity, in western countries such as in Spain, are counted as the 'normal' things to be talked in public (Spanish Manual). For that reason, it can be concluded that Indonesia and Spain are two countries with vastly different cultural backgrounds.

Erotism is a matter that leads to sexual activity. According to Kamus Besar Bahasa Indonesia (KBBI) online, erotism or eroticism is the state of the rise of lust (Erotisisme). Bataille (1986) defined erotism as a special things related to sexual activity, with the main intention of the activity is to reproduce descendants. However, erotism cannot be easily described. Even so, the definition of erotism always leads to sexual attraction that sometimes is equated with pornography (Fellmann \& Walsh, 2016). Fellmann and Walsh (2016) added that generally, erotism drives to sexual fantasy and imagination.

The studies regarding erotism and vulgarity in a song have been researched numerously. One of those was a study conducted by Dukes, Bisel, Borega, Lobato, and Owens (2003) that tried to discover the relationship between 1958 - 1998 American hits with American culture. Finally, it was found that before the emergence of women movement in 1998, the song lyrics produced were mostly concerning on how love was pictured as something sweet, passionate, and intimate. While in contrast, the song lyrics produced after 1998 were predominantly about the independence of women. Another study was authored by Asofah, Karima, and Larasati (2016). They aimed to uncover the influence of erotic song lyrics to the young generation of Indonesia. By using Indonesian pop songs from 2000 - 2015, they attained the result that the young generation had a desire to perform what they heard in a song. In this case, the songs with erotic lyrics can be said as triggers for the youth in doing sexual activity. Furthermore, in addition to the previous studies, Merwe (2017) also piloted a study regarding erotic fantasy in a song. However, the song that Merwe (2017) decided to use as the objects of the study was Song of Songs, a song written in Bible. In result, Merwe (2017) obtained that even though the word of sex did not found in the song lyrics, implicitly, Song of Songs told the fantasy about a beautiful women, which later on, this lead the readers and song lovers to enjoy the beauty of erotic love. Although quite numerous studies regarding songs and erotism have been conducted, nonetheless, the study about erotism in a song and its relation to the culture are still rare. For that reason, this study aims to uncover how two different cultures, namely Spanish and Indonesian cultures, depict erotism and vulgarity in song productions.

\section{Methodology}

This study applies the descriptive qualitative approach, in which the data analysis is done based on the writer's interpretation and related to the cultural background of the country a song is produced. In this study, the objects used are the song lyrics of one Spanish song and one Indonesian song that are believed to have correlation with erotism. The Spanish song used is entitled Despacito, sung by Luis Fonsi. This song has earned 5.2 billion views in YouTube during the first year of its release date. As for the Indonesian song, the song used is entitled Belah Duren, performed by Julia Perez, that is said to be quite sensational due to its erotic lyrics (Romdlon, 2017). Bothsong lyrics were translated into English before they were scrutinized. To be noticed, the English translation of Despacito is available online, while the translation of Belah Duren was performed manually by utilizing literal translation method. After that, both lyrics written in English were compared before related to Spanish and Indonesian cultures, respectively, in order to figure out the depiction of erotism in those song lyrics.

\section{Results and discussion}

From the two obtained song lyrics, it can be seen that both in Luis Fonsi's Spanish song lyrics and in Julia Perez's Indonesian song lyrics include the words that are erotism-related. Nevertheless, both song lyrics have its own characteristics that differs one another in showing the erotic contexts in the song. Below are the elucidations of both songs. 


\subsection{Despacito by Luis Fonsi (Spain)}

In Luis Fonsi's song, for instance; his song entitled Despacito, meaning 'slowly' in English, does not depict any sexual context. However, if observed from one-line or one-verse lyrics that form one sentence or sequence, the meaning of despacitothat is previously considered neutral (slowly) experiences meaning shifts, according to the song's context. For instance, the depiction can be analyzed from the lyrics espacito, quierorespirartucuellodespacito, deja que tedigacosas al oído, para que teacuerdessi no estásconmigothat are written in one verse. The lyrics mean 'slowly, I want to breathe in your neck slowly, let me whisper in your ears, so you can remember if you're not with me' in English. Because of that, it can be implied that the meaning of despacito is shifting quite a bit, caused by the sequence of the sentence that follow the word, in which the phrases as breathe your neckand whisper in your ears more or less lead to sexual contexts and are closely related to erotism.

Furthermore, if examined from another verse, it seems clearer that the word despacitoin Luis Fonsi's song does not literally mean slowly in neutral connotation. On the contrary, the meaning of despacito itself is seemingly to be turned into a process leading to sexual activity. This can benoticed from the lyrics in the next verse; despacito, quierodesnudarte a besosdespacito,firmoen las paredes de tulaberinto, y hacer de tucuerpotodo un manuscrito, which means 'slowly, I want to undress you slowly while kissing you, entering the walls of your labyrinth, and make your body a whole manuscript.' Generally, the common understanding of a sentence such as I want to undress you while kissing you slowly has the connotation of something that is related to erotism, particularly to sexual activity. Those claims are strengthen by the phrase entering the walls of your labyrinth and make your body a whole manuscript, which forms the new meaning related to sexual activity if merged to the previous sentences. In other words, the lyrics in that verse indirectly imply how someone does sexual activity, started from the process of undressin the partner slowly to the penetration process, marked by the phrase entering the walls of your labyrinth. Captivatingly, the lyrics that have been elucidated beforehand are placed as the refrain of the song, which makes it to experience several repetitions. Thus, it can be stated that tacitly, the verses containing erotic lyrics can be said as the 'core' of the song entitled Despacito itself.

Not only has that, in the next verse, the same occurrence also appeared. Usually, 'dance' and 'rhythm' convey the same neutral connotation related to art, particularly music art. If analyzed from the complete sentence; quieroverbailartupelo and quiero ser turitmo, the neutral connotation of those two phrases can still be recognized, providing the literal meaning of those phrases are 'I want to see your dance' and 'I want to follow your rhythm', respectively. However, in this song, the words 'dance' and 'rhythm' are discovered having different conotations, especially after being related to the sentences that follow as well as to the context of the song. In Despacito's song lyrics, after the sentences including the words dance and rhythm, it is mentioned that que le enseñes a mi boca, tuslugaresfavoritos, which means 'that you reach my mouth, your favorite places'. From this, it can be noticed that the previous two sentences experience meaning shift, from the neutral one to the erotism-related one that can lead to sexual activity. Besides, in the following verse, the song lyrics of Despacito explain the desire to undertake the game to the next level. For instance, the lyrics déjamesobrepasartus zonas de peligro, hasta provocartusgritos that have the translation of 'let me surpass your danger zones, to provoke your scream,' seems to be eludating the meaning of the phrase danger zones, which is a person's private area.

In addition, the word explore that tends to have a neutral connotation, in this song, have another meaning. If observed from the lyricsyo no tengoprisa, yo me quierodar el viaje, the meaning of explore is still neutral, affording the translation of that lyrics is 'I'm not in a hurry, I want to explore.' Conversely, similar to the lyrics in the previous verses and if conjuncted to the following lyrics, the meaning of explore experiences meaning shift. Empecemos lento, despuéssalvaje, or in English is translated into 'let's start slow, then wild' is the following lyrics of the prior two sentences. Along these lines, an understanding can be inferred; that the word explore does not mean doing the exploration of language acquisition, feelings, or the 
relationship between social classes as described in Merriam Webster Dictionary, yet, its connotation can be related with exploring someone's body that associated with erotism.

\subsection{Belah Duren by Julia Perez (Indonesia)}

Different from the elucidation regarding Despacito song lyrics, sung by Spain's Luis Fonsi, in the second song, which is the Indonesian song entitled Belah Duren, or 'splitting durian' in English, the sentences or phrases containing erotic meanings tend to be more implicitly written. In the first verse, the lyrics makan duren di malam hari, paling enak dengan kekasih, dibelah, bang, dibelah, enak, bang, silah kandibelah, or in English can be literally translated as 'eating durian at night is best done with your lover, split it, split it, it is good, please split it.' Literally, referring to Kamus Besar Bahasa Indonesia (KBBI), every word in those lyrics have fairly neutral connotation and not related to erotism. In description, none of the words as makan (eating), duren (which means 'durian' in Javanese), kekasih (lover), and dibelah (split) is close to erotism nor vulgarity. In addition, in the next verse, the lyrics jangan lupa mengunci pintu, nanti ada orang yang tahu, pelan-pelan dibelah, enak, bang, silahkan dibelah, the explicit erotic issue can barely be discovered, bestowing the English translation is 'do not forget to lock the door, people will notice, slowly, split it slowly.'

Despite of the explanation of the song lyrics of Belah Duren before, in the next verses, the issue of erotism starts to be revealed. The sentence as semua orang pasti suka belah duren, or in English means 'everyone must like splitting durian', in verity, has neutral connotation. Even so, in this circumstance, the sentence is associated to the ensuing lyrics, to be precise the lyrics of apalagi malam pengantin. The phrase as 'particularly in wedding nights,' the translation of the lyrics, is commonly apprehended as sexual activity performed by wedding couple. Because of that, it cannot be disregarded that this part of the lyrics bring different senses to the song as a whole. Other than that, the subsequent sentences as yang satu ini durennya luar biasa, bisa bikin abang gak tahan, sampai-sampai ketagihan, which is translated into 'this durian is amazing that you cannot resist and makes you addicted' in English, strengthens the assumption that the meaning of belah duren or splitting durian in the song is not literally splitting durian. In contrast, the connotation of the phrase shifts to erotic connotation that leads to the process of sexual activity, in which the 'durian' conveys the meaning of women's reproduction area.

\subsection{Discussion}

From the elucidations of the song lyrics chosen as the objects of this study, namely Spanish song, Despacito, and Indonesian song, Belah Duren, several implications can be inferred. The first one is that in Spanish culture, especially as depictedin Despacito song lyrics, the exposition of erotism and vulgarity is reputed as part of entertainment that is normal to be talked publicly. This can be seen from the numerous explicit words directing to erotism, such as breathe in your neck, undress you slowly, whisper in your ears, and entering the walls of your labyrinth. Interestingly, these things are considered common in Spanish culture. Ever since 1962, Spain has been opened up to the things associated with nudity (Sofia). Other than that, the objects as human's body and lust are pondered as original phenomena of Spain that is believed to be able to attract foreign vacationers to visit Spain (Sofia). In addition, in Spain, erotism can be discovered in many other media as entertainment, such as films and local television shows. Moreover, in Despacito song lyrics, the sentence 'this is how we do it down in Puerto Rico' is also detected, strengthening the assumption that in Spain, particularly in Puerto Rico, the things as uttered in this song is the usual things to do.

The second implication that can be supposed is that in Indonesian culture, the conveyance of erotic and vulgar matters are still considered taboo that makes it to be implicitly affirmed. In consequence, that is pictured in the song lyrics of Belah Duren. Furthermore, another interesting fact is that the genre of those two songs are different. Unlike in Spain where songs with erotic meanings can be noticed in pop genre, in Indonesia, the songs that convey erotic meanings are mostly discovered in the genre of dangdut. This assertion is supported by a claim stated that 
dangdut music is closely related to every day life situation, particularly with the situation in which prostitution, alcohol, and sexuality are included (Barker, 2011). Other than that, Barker (2011) declared that dissimilar to other music genres in Indonesia, dangdut tends to reflect more of sociocultural situation in Indonesia. Because of that, it can be reckoned that the song lyrics of Belah Duren that implicitly conveys erotic meanings might have correlation with Indonesian culture that sees such things as taboo andcannot be liberally expressed, even though in the form of art.

\section{Conclusion}

The Spanish people are assumed to be known for their freedom in expressing objects conveying erotism and vulgarity. This can be seen from the song lyrics of one of Spanish song entitled Despacito. In that song, the discovery of explicit lyrics regarding erotism and sexual activity are massive, such as breathe in your neck, undress you slowly, whisper in your ears, and entering the walls of your labyrinth. Apparently, this kind of thing matches with Spanish culture that considers human's body an art and an attraction to invite foreign visitors. On the contrary, in Indonesian song lyrics entitled Belah Duren, the things that are related to erotism and vulgarity are implicitly expressed by using figurative of speech. One of those is by replacing the term for women's genitals with the word duren or 'durian' in English. Enchantingly, this, perhaps, does not surprising, providing in Indonesia, the talks about sex and erotism are still considered taboo. From this explanation, it can be inferred that the majority of Indonesian people still obey their collectivism culture, in which everything against the norms and customs is not commonly talked publicly. While on the other hand, Spanish people tend to be more tolerant in talking things regarding erotism and vulgarity publicly, as long as it does not violent the law.

\section{References}

Asrofah, Karima, F. H., \& Larasati. 2016. Language fetishism in Indonesian popular songs and its influence to Indonesian's young generation. IOSR Journal Of Humanities And Social Science, 21(11), 21-25.

Bataille, G. 1986. Erotism: Death and sensuality. San Francisco: City Lights Book.

Dakroury, A. 2014. Editorial: Media and culture. Global Media Journal -- Canadian Edition, $7(2), 1-3$.

Dangdut, The Sound of Indonesia. Available at https://iias.asia/sites/default/files/IIAS_NL57_36.pdf. (Accessed 5 June 2018).

Delaney, T. 2015. Pop Culture: An Overview. Available at Philosophy Now: https://www.csub.edu/ bruff/Pop\%20Culture\%20Article\%201.pdf. (Accessed 5 June 2018).

Despacito ft. Daddy Yankee. Available at https://www.youtube.com/watch?v=kJQP7kiw5Fk. (Accessed 5 June 2018).

Dukes, R. L., Bisel, T. M., Borega, K. N., Lobato, E. A., \& Owens, M. D. 2003. Expressions of love, sex, and hurt in popular songs: A ontent analysis of all-time greatest hits. The Social Science Journal, 40, 643-650.

Erotisisme. Available at https://kbbi.kemdikbud.go.id/entri/erotisisme. (Accessed 6 June 2018).

Fellmann, F., \& Walsh, R. 2016. From sexuality to eroticism: The making of the human mind. Advances in Anthropology, 6, 11-24.

Julia Perez-Belah Duren [Official Music Video]. Available at https://www.youtube.com/watch?v=Ises4CDix2U. (Accessed 5 June 2018).

Lirik Lagu Barat. Available at https://www.lirik-lagu.com/2017/04/lirik-lagu-despacito-justinbieber-ft.html. (Accessed 5 June 2018).

Lirik Lagu Belah Duren-Julia Perez. Available at https://lirik.kapanlagi.com/artis/juliaperez/belah-duren/. (Accessed 5 June 2018).

Merwe, D. G. 2017. Erotic fantasy, spirituality and song of songs. Verbum et Ecclesia, 1-9. 
Romdlon, N. 2017. Selain 'Becekin Adek Bang', Ini 5 Lagu yang Dihujat karena Lirik Vulgar. Available at https://www.brilio.net/musik/selain-becekin-adek-bang-ini-5-lagu-yangdihujat-karena-lirik-vulgar-1703216.html. (Accessed 5 June 2018).

Sofia, R. (n.d.). "Spain is Different". Tourism and apertura in 1960s Spain. Museo Nacional Centro de Arte.

$\begin{array}{llll}\text { Spanish } & \text { Manual. } & \text { (n.d.). available }\end{array}$ http://languagemanuals.weebly.com/uploads/4/8/5/3/4853169/spanishmanual.pdf. (Accessed 5 June 2018)

Triandis, H. C. 2001. Individualism-collectivism and personality. Journal of Personality, 69(6), 907-924. 